\title{
EFFECT OF CALIFORNIAN RED WORM (Eisenia foetida) ON THE NUTRIENT DYNAMICS OF A MIXTURE OF SEMICOMPOSTED MATERIALS
}

\author{
Hugo Castillo $^{1 *}$, Adriana Hernández², David Dominguez ${ }^{1}$, and Damaris Ojeda²
}

\begin{abstract}
The efficiency of composting processes with and without the addition of Californian red worms (Eisenia foetida) was evaluated, using manure of dairy cows to generate organic fertilizer. Several parameters were assessed as physiochemical indicators of maturity, such as temperature, $\mathrm{pH}, \mathrm{C} / \mathrm{N}$ ratio, phytotoxicity and macro and micronutrients at 25 and 54 wk (mature and stored products, respectively). A linear model was used in the statistical analysis, with four replicates that included as fixed effects, the composting systems and time. At 25 wk, both systems reduced the $\mathrm{C} / \mathrm{N}$ ratio to values of 15.5 in vermicompost and $17.1 \mathrm{in}$ semi-compost. The content of total $\mathrm{N}, \mathrm{N}-\mathrm{NO}_{3}, \mathrm{Ca}$ and some micronutrients also increased. $\mathrm{K}$ and $\mathrm{Na}$ concentrations were higher in the compost than in the vermicompost. The mean of $\mathrm{pH}$ presented differences in the two systems of decomposition. The germination index, using lettuce seeds (Lactuca sativa L.) var. Grandes Lagos in vitro, of the decomposition products increased in week 25, indicating the degree of maturity reached. The effect of storage was greater stability of the products by reducing the $\mathrm{C} / \mathrm{N}$ ratio to 8.13 for vermicompost and 7.05 for compost, as well as an increase in available $\mathrm{N}$ content in the form of $\mathrm{N}^{-\mathrm{NO}_{3}}$ in the case of compost and in the content of $\mathrm{Ca}, \mathrm{Mg}, \mathrm{Na}, \mathrm{Zn}, \mathrm{Mn}$ and $\mathrm{Cu}$ in both systems.
\end{abstract}

Key words: fertilizer, organic, maturation, stability.

\section{INTRODUCTION}

Inadequately managed manure can cause environmental problems. Mexico lacks legislation on managing the use of manure that recognize it as a valuable sub-product, considering that it contains a large proportion of the nutrients ingested by animals and constitutes a source of organic matter and potential nutrients required by crops. This availability increases when the organic matter and the nutrients are transformed through chemical-biological processes like composting (Kowalchuk et al., 1999; Mondini et al., 2003). Dairy herds in state of Chihuahua in northern Mexico generate around $312609 \mathrm{t}$ (based on dry weight) of manure per year (NRAES, 1999; Jurado, 2004). Traditionally, this manure has been incorporated into agricultural soils to increase the organic matter content and as a source of $\mathrm{N}$ for crops. However, this application is generally not done appropriately, taking

\footnotetext{
${ }^{1}$ Universidad Autónoma de Chihuahua, Facultad de Zootecnia y Ecología, V. Carranza y Escorza s/n. Colonia Centro, CP 31000 , Chihuahua, México. *Corresponding author (hcastillo@uach.mx). ${ }^{2}$ Universidad Autónoma de Chihuahua, Facultad de Ciencias Agrotecnológicas, V. Carranza y Escorza s/n. Colonia Centro, CP 31000, Chihuahua, México.

Received: 04 August 2009.
}

Accepted: 20 January 2010. into account the soil characteristics and nutritional requirements of crops, which can result in damage to the health of the ecosystem, such as the salinization of soils, the lixiviation of nitrates to aquifers and the runoff of nitrates and phosphates to surface water bodies. This problem indicates that manure is an important reservoir of contaminants that can potentially affect humans, or from another perspective, a novel potential industry with important applications.

An alternative to reduce the environmental impact of manure is its treatment through composting. During this process, manure and other waste material are mixed in proportions such that the $\mathrm{C} / \mathrm{N}$ ratio, humidity and adequate aeration can stimulate microbial activity that modifies the chemical and physical structure of the materials. Among the most commonly used techniques are traditional composting, in which the materials are mixed manually or mechanically, and vermicomposting, where species of annelids are added, commonly the Californian red worm (Eisenia foetida), which provoke mixing and constant aeration of the materials, as well as providing digestive enzymes that influence the decomposition of organic matter (Santamaría-Romero et al., 2001). The latter system has had an important increase in agricultural zones in central and southern Mexico, where vermicompost is also considered a natural 
pesticide and is used with diverse agricultural crops. However, in comparison to traditional composting, vermicomposting requires a higher initial investment of capital and a higher technical capacity to ensure the viability of the annelids.

Ferrera and Alarcón (2001) and Nogales et al. (2005) indicated that both biotechnological processes are excellent for preparing agricultural manures and that in the specific case of vermicomposting, the material obtained is considered chemically and biologically enriched. However, several specific aspects of the process, such as the nutrient balance and its potential activity as a suppressor of microorganisms that are pathogenic to humans, have not been explored following an adequate scientific model.

The objective of this work was to evaluate the changes in physiochemical and nutritional characteristics of compost and vermicompost during the process of maturation and after $29 \mathrm{wk}$ of storage.

\section{MATERIALS AND METHODS}

\section{Description of the site}

The work was carried out at the Faculty of Agrotechnological Sciences of the Universidad Autónoma de Chihuahua, Chihuahua, Mexico. The maturation process lasted 25 wk (175 d), beginning December 2006 until June 2007. A mixture was prepared using two types of organic residues, manure from a herd of dairy cows and pine sawdust. The mixture was submitted to two systems of decomposition referred to as composting and vermicomposting. The containers with the substrate were protected from the environment with a plastic tunnel constructed with metal rods and semi-transparent plastic, with a maximum height of 40 $\mathrm{cm}$. The structure was intended to protect the containers from rain and control humidity loss during the $25 \mathrm{wk}$ of maturation of the substrates. Subsequently, the products were stored for $29 \mathrm{wk}$ ( $203 \mathrm{~d}$ ) in polyethylene bags at ambient temperature.

\section{Manure and the preparation of the compost}

Fresh cow manure was obtained from the dairy herd of the Faculty of Animal Husbandry and Ecology of the Universidad Autónoma de Chihuahua. The herd was composed of 2-to-5-yr-old Holsteins confined in an areas of $50 \times 40 \mathrm{~m}$ and fed on a base of rolled corn (Zea mays L.), wheat bran (Triticum aestivum L.), ground cotton seed, soya paste, alfalfa (Medicago sativa L.) and corn silage. Finely-particled pine sawdust $(<2 \mathrm{~mm})$ was obtained from a local sawmill.

For the decomposition systems, a mixture was prepared of cow manure and sawdust with an initial
$\mathrm{C} / \mathrm{N}$ ratio of $25 / 1$, as recommended in previous works (Hansen et al., 2001; Soto and Muñoz, 2002). The program "Moisture and C/N Ratio Calculation", developed by Richard (1995), was used to determine the required quantity of each residual. The initial mixture was deposited in eight thick 58-L plastic containers with dimension of $36 \times 58 \times 28 \mathrm{~cm}$ (Santamaría-Romero, 2001; Nogales et al., 2005). Four containers were used for the composting system and four for vermicomposting. The mixture was removed each week from the containers for composting to increase aeration and reduce the formation of anaerobic zones. In the case of vermicomposting, once the mixtures were made, they were submitted to a process of pre-composting for $15 \mathrm{~d}$. Californian red worms were then seeded with a population of 580 adult worms per experimental unit, that is, 10 worms $\mathrm{L}^{-1}$. Irrigation with distilled water was done according to the criterion of maintaining the humidity of the substrate at $70-80 \%$ in the vermicomposting treatment and at 50$60 \%$ in the compost treatment (NRAES, 1999; Soto and Muñoz, 2002).

\section{Physiochemical analysis}

The temperature of the mixture was monitored for the 25 wk of maturation by inserting a thermometer to a depth of $20 \mathrm{~cm}$ at the center of each container every $48 \mathrm{~h}$ at 12:00 $\mathrm{h}$. The ambient temperature was recorded using a maximum-minimum thermometer (Fisher Scientific, Pittsburgh, Pennsylvania, USA). The day before sampling, the compost was manually homogenized within each container. Five samplings were taken for nutritional analysis at weeks $0,4,10,21$ and 25 , during which organic, total $\mathrm{N}, \mathrm{NO}_{3}, \mathrm{P}, \mathrm{K}, \mathrm{Ca}, \mathrm{Mg}, \mathrm{Na}, \mathrm{Cu}, \mathrm{Fe}, \mathrm{Mn}$, $\mathrm{Zn}$ and $\mathrm{pH}$ were quantified. To measure these elements, approximately $200 \mathrm{~g}$ of compost was weighed, dried in an oven at $60{ }^{\circ} \mathrm{C}$, sieved through a $\mathrm{N}^{\circ} 20$ mesh and packed in polyethylene bags in triplicate. Total $\mathrm{N}$ was quantified

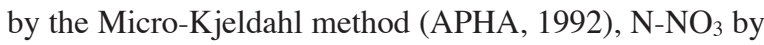
the Brucina method and UV-visible spectrophotometry (APHA, 1992), $\mathrm{Ca}, \mathrm{Mg}, \mathrm{K}, \mathrm{Na}, \mathrm{Cu}, \mathrm{Fe}, \mathrm{Mn}$ and $\mathrm{Zn}$ ions by digestion with aqua regis (nitric acid and perchloric acid in a 3:1 ratio) (Nogales et al., 2005) and atomic absorption spectrophotometry (Perkin Elmer Analyst 100, New Jersey, USA), total P with the vanadiummolybdenum ammonium and analysis with UV-visible spectrophotometry, organic $\mathrm{C}$ using the method proposed by ASTM (2000) and pH using a potentiometer (Accumet AB15, Fisher Scientific, USA) in a dilution in water 1:5 $(\mathrm{w} / \mathrm{v})$.

\section{Phytotoxicity assay}

The degree of phytotoxicity of the composting products was assessed with the calculation of a germination index 
previously used by Zucconi et al. (1981) and Celis et al. 2006. Lettuce seeds (Lactuca sativa L.) var. Grandes Lagos were used for this assay with the following protocol: composting and vermicomposting products at $54 \mathrm{wk}$ (after storage) were sieved with mesh of 4,5 mm in diameter and re-suspended in de-ionized water in a 1:10 ratio. The mixture was agitated horizontally for 1 $\mathrm{h}$ and centrifuged at $5000 \mathrm{rpm}$ for $15 \mathrm{~min}$. Some $5 \mathrm{~mL}$ of each extract was transferred to sterile Petri boxes, in which 20 seeds were placed, as well as filter paper to maintain a moist environment. The boxes were placed in a dark germination chamber at a constant temperature of $22{ }^{\circ} \mathrm{C}$. Distilled water was used as a negative control for inhibiting germination and a solution of $\mathrm{Zn} 0.001 \mathrm{M}$ prepared from $\mathrm{ZnSO}_{4}$ was used as a positive control. The germination was calculated according to the equation $\mathrm{IG}=(\mathrm{G} \times \mathrm{L}) /(\mathrm{Go} \times \mathrm{Lo}) \times 100$, where $\mathrm{G}=$ percentage of germination, $\mathrm{L}=$ length of root growth and Go/Lo are the parameters in the negative control. There were a total of four experimental units for each of the four replicate of each treatment.

\section{Statistical analysis}

A linear model was adjusted to analyze the data. The model included as fixed effects, the effects of composting and vermicomposting systems; the effect of time over the weeks of observation; and the interaction among them. A linear model was adjusted for the germination index, which included the composting method as a fixed effect. For the variable of storage period, a linear model was adjusted that included storage time as a fixed effect. The variance analysis was made using the PROC GLM command in the SAS program, version 8.2 (SAS Institute, 2001). The means comparison was made using orthogonal contrasts.

\section{RESULTS AND DISCUSSION}

The ambient temperatures and substrates recorded for $25 \mathrm{wk}$ are shown in Figure 1. The behavior of the temperature of the substrate was very similar in the two systems, although an effect was observed $(\mathrm{P}<0.0001)$ in the interaction between composting system and time. Both systems presented temperatures higher than $20^{\circ} \mathrm{C}$ during the first $2 \mathrm{wk}$, indicating the beginning of the composting process, corresponding to the lower limit of the mesophilic stage $\left(20-40{ }^{\circ} \mathrm{C}\right)$, even though ambient temperatures registered much lower values. However, during the following $6 \mathrm{wk}$ the temperature of the substrates decreased to $8{ }^{\circ} \mathrm{C}$, with a subsequent increase to between 17 and $28.3{ }^{\circ} \mathrm{C}$ beginning on week 8 until the end of the process, so that the expected thermphilic phase, with temperatures of $60-70{ }^{\circ} \mathrm{C}$, was not presented in this study. The temperature of the substrates had a similar behavior to that of ambient temperature, always maintaining intermediate values between maximum and minimum temperatures.

Temperature is one of the most important factors governing the velocity of biochemical reactions in composting (Defrieri et al., 2005) and an adequate maturation of the compost. The ambient temperatures of the station during this study, as well as the total volume of the containers (less than $1 \mathrm{~m}^{3}$ ) can explain the low temperatures of the substrate, which did not reach the temperatures expected for the thermophilic phase (60$70{ }^{\circ} \mathrm{C}$ ). This suggests a possible reduction in microbial activity and the absence of the microorganisms expected in this phase, in comparison to other experiments. The substrate under the vermicomposting decomposition system in this study presented mean temperatures within the growth range established for worms for the major

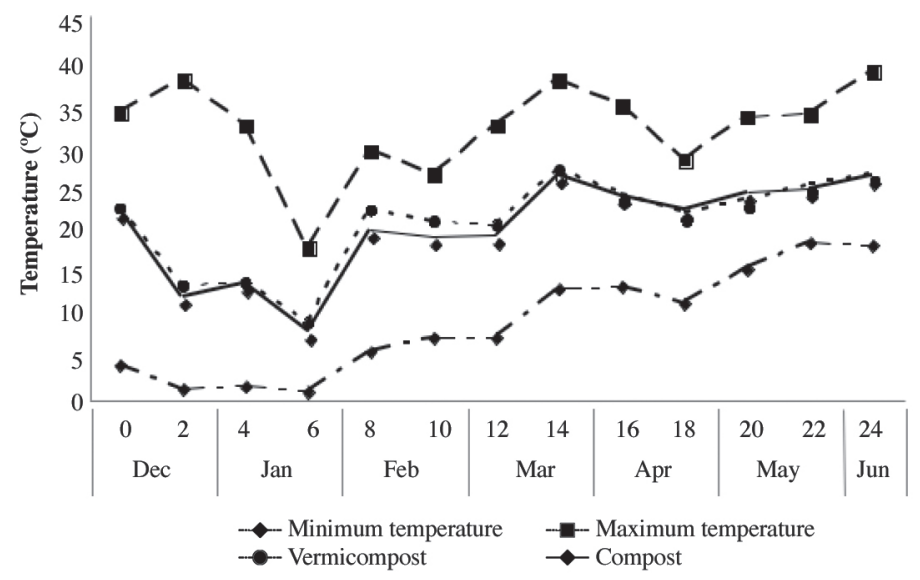

Figure 1. Variation of maximum and minimum temperatures and of the reactors with compost and vermicompost during the composting period, December 2006 to June 2007. Temperature values are the mean of eight observations. 
part of the process, and there were optimal temperatures beginning in week 13 of the study.

The $\mathrm{pH}$ value of the studied mixtures presented an effect of the composting system/time interaction $(\mathrm{P} \leq 0.0001)$. The final mean of $\mathrm{pH}$ by composting presented a value of $8.5 \pm 0.09$ and de $7.2 \pm 0.09$ units for vermicompost, which are significantly different $(\mathrm{P} \leq$ 0.0001 ) in $1.23 \pm 0.14$ units (Table 1 ). The $\mathrm{pH}$ value of the compost in the present work was higher than what is traditionally reported as normal, with a $\mathrm{pH}$ value of 7.8. As well, the compost presented higher levels of the alkaline cations $\mathrm{K}, \mathrm{Mg}$ and $\mathrm{Na}$, which can also have influenced its behavior. In vermicomposting, the $\mathrm{pH}$ of the medium plays a very important role in directly influencing worm alimentation and reproduction, preferring $\mathrm{pH}$ values close to 7.0 .

Organic $\mathrm{C}$ presented the effect of the composting system/time interaction $(\mathrm{P}>0,014)$. The study began with mixtures prepared from base residues seeking a $25 \%$ concentration of organic C. The means of organic $\mathrm{C}$ concentration found in the analysis of the samples at week 0 presented variation from the desired concentration for both systems, with $20 \%$ in vermicompost and $23.14 \%$ in compost. This could be because of the difficulty of homogenizing the initial mixture owing the physical characteristics of the fresh manure and sawdust (Table 1). This variation was reduced in the following sampling 4 wk after, when the concentrations of organic $\mathrm{C}$ tended to equalize (20.75$20.01 \%$ ). There was a decrease in the concentration of organic $\mathrm{C}$ in week 25 , with a concentration of $21.4 \%$ for the final product of vermicompost and $24 \%$ for that of compost, without these differences being significant in $(\mathrm{P} \leq 0.0703)$, which suggests the partial mineralization of a fraction of organic $\mathrm{C}$ as the composting process advanced or volatilization in the form of $\mathrm{CO}_{2}$. The results obtained in this research, in which organic $\mathrm{C}$ content behaved cyclically, have been reported before and in different systems (Madrid and Castellans, 2001). The statistical analysis shows that there was no effect of the composting system/time interaction $(\mathrm{P} \leq 0.8917)$ on the variable total $\mathrm{N}$. However, the factor of the composting system had a significant effect $(\mathrm{P} \leq 0.0041)$ on total $\mathrm{N}$ concentration, presenting minimum mean squares of $1.34 \pm 0.04 \%$ in the vermicompositng system and 1.18 $\pm 0.04 \%$ in the composting system, which represents a difference of $0.16 \pm 0.053$ units (Table 1). The time factor had a quadratic effect $(\mathrm{P} \leq 0.04)$ on the variable total $\mathrm{N}$. The experiment began with mixtures of fresh cow manure and sawdust seeking an $\mathrm{N}$ content of $\mathrm{N}$ content of $1 \%$, which was achieved satisfactorily.

The $\mathrm{C} / \mathrm{N}$ ratio equal to $25 / 1$ established at the beginning of the experiment is an adequate ratio to ensure $\mathrm{N}$ mineralization. There was a general tendency for this nutrient to increase in the substrate since the beginning of decomposition, which indicates that $\mathrm{N}$ fixing and volatilization were not present. Total $\mathrm{N}$ concentration was concentrated in both types of composting in the final stages of the process, which is the expected behavior owing to the effect of the loss of organic matter (SantamaríaRomero et al., 2001). Equally, the low temperatures, the decrease in $\mathrm{pH}$ and the moisture of the residues favored

Table 1. Comparison of $\mathrm{pH}$ and macro and micronutrients between mature vermicompost and compost (week 25) and stored (week 54). The values correspond to the mean of six observations.

\begin{tabular}{|c|c|c|c|c|c|c|c|}
\hline \multirow[b]{2}{*}{$\begin{array}{l}\text { Variable } \\
\text { (dry weight) }\end{array}$} & Vermicompost & Compost & Vermicompost & Compost & \multicolumn{3}{|c|}{ Contrasts } \\
\hline & \multicolumn{2}{|c|}{ Week 25} & \multicolumn{2}{|c|}{ Week 54} & $\begin{array}{c}25 \text { vs. } \\
54\end{array}$ & $\begin{array}{c}\text { Verm } \\
25 \text { vs. } 54\end{array}$ & $\begin{array}{c}\text { Comp } \\
25 \text { vs. } 54\end{array}$ \\
\hline $\mathrm{pH}$ & $7.29 \pm 0.1$ & $8.53 \pm 0.1$ & $6.0 \pm 0.1$ & $7.42 \pm 0.1$ & $<0.0001$ & $<0.0001$ & $<0.0001$ \\
\hline $\mathrm{C}, \%$ & $24.08 \pm 1.2$ & $21.40 \pm 1.2$ & $18.57 \pm 1.2$ & $14.91 \pm 1.2$ & 0.0186 & 0.0059 & 0.0020 \\
\hline N-total, \% & $1.61 \pm 1.1$ & $1.42 \pm 1.1$ & $2.24 \pm 1.1$ & $2.20 \pm 1.1$ & 0.3331 & 0.0017 & 0.0003 \\
\hline $\mathrm{C} / \mathrm{N}$ & $15.50 \pm 1.4$ & $17.07 \pm 1.4$ & $8.13 \pm 1.4$ & $7.07 \pm 1.4$ & 0.8636 & 0.0032 & 0.0003 \\
\hline $\mathrm{N}^{-\mathrm{NO}_{3}}, \mathrm{mg} \mathrm{kg}^{-1}$ & $345 \pm 67$ & $346 \pm 67$ & $532 \pm 67$ & $769 \pm 67$ & 0.1004 & 0.0705 & 0.0008 \\
\hline $\mathrm{P}, \%$ & $0.014 \pm 0.0009$ & $0.015 \pm 0.0009$ & $0.006 \pm 0.0009$ & $0.007 \pm 0.0009$ & $<0.0001$ & 0.0001 & $<0.0001$ \\
\hline $\mathrm{K}, \%$ & $0.22 \pm 0.05$ & $0.55 \pm 0.05$ & $0.79 \pm 0.05$ & $0.22 \pm 0.05$ & 0.0312 & $<0.0001$ & 0.0004 \\
\hline $\mathrm{Ca}, \%$ & $0.63 \pm 0.09$ & $0.61 \pm 0.09$ & $1.33 \pm 0.09$ & $0.95 \pm 0.09$ & $<0.0001$ & $<0.0001$ & 0.0152 \\
\hline $\mathrm{Mg}, \%$ & $0.21 \pm 0.03$ & $0.27 \pm 0.03$ & $1.21 \pm 0.03$ & $0.84 \pm 0.03$ & $<0.0001$ & $<0.0001$ & $<0.0001$ \\
\hline $\mathrm{Na}, \%$ & $0.08 \pm 0.007$ & $0.140 \pm 0.007$ & $0.12 \pm 0.007$ & $0.26 \pm 0.007$ & $<0.0001$ & 0.0061 & $<0.0001$ \\
\hline $\mathrm{Fe}, \mathrm{mg} \mathrm{kg}^{-1} \mathrm{DM}$ & $991 \pm 37$ & $1049 \pm 37$ & $357 \pm 37$ & $367 \pm 37$ & $<0.0001$ & $<0.0001$ & $<0.0001$ \\
\hline $\mathrm{Zn}, \mathrm{mg} \mathrm{kg}^{-1} \mathrm{DM}$ & $76 \pm 4$ & $69 \pm 4$ & $91 \pm 4$ & $86 \pm 4$ & 0.0023 & 0.0265 & 0.0131 \\
\hline $\mathrm{Mn}, \mathrm{mg} \mathrm{kg}^{-1} \mathrm{DM}$ & $141 \pm 10$ & $145 \pm 10$ & $196 \pm 10$ & $213 \pm 10$ & $<0.0001$ & 0.0026 & 0.0005 \\
\hline $\mathrm{Cu}, \mathrm{mg} \mathrm{kg}^{-1} \mathrm{DM}$ & $16 \pm 2$ & $15 \pm 2$ & $38 \pm 2$ & $41 \pm 2$ & $<0.0001$ & $<0.0001$ & $<0.0001$ \\
\hline
\end{tabular}


the increase in total $\mathrm{N}$ content, which corresponds to the conditions observed in the vermicomposting system.

The $\mathrm{C} / \mathrm{N}$ ratios of the studied mixtures showed the effects of the composting system/time interaction ( $\mathrm{P}$ $\leq 0.005)$. The experiment was initiated with mixtures prepared from base residues, seeking a $\mathrm{C} / \mathrm{N}$ ratio equal to $25 / 1$. The means of $C$ concentration found in the analysis of the initial samples presented a slight variation from the desired $\mathrm{C} / \mathrm{N}$ ratio of $16.1 \pm 1.39$ for vermicompost and $21.9 \pm 1.39$ for compost. This could be because of the difficulty in homogenizing the initial mixture. This variation decreased four weeks after, when the ratio tended to equalize and decrease to $15.8 \pm 1.39$ for vermicompost and $17.4 \pm 1.39$ for compost. Subsequently, there was an increase in the $\mathrm{C} / \mathrm{N}$ ratio during weeks 10 and 21, in which means were observed between $22.6 \pm 1.39$ and 34.4 \pm 1.39 , characteristic of fresh residues, rich in cellulose and lignin.

The changes in the relative concentration of organic $\mathrm{C}$ and total $\mathrm{N}$ previously described caused a decrease in the $\mathrm{C} / \mathrm{N}$ ratio toward the end of the experimental period, observing a $\mathrm{C} / \mathrm{N}$ ratio of $15.5 \pm 1.39$ units for the final product of vermicompost and $17.0 \pm 1.39$ for that of the compost, which was not a significant difference ( $\mathrm{P}$ $\leq 0.430$ ). According to several authors, a compost is considered stable and mature when the $\mathrm{C} / \mathrm{N}$ ratio lower than (Nogales et al., 2005) or close to 15 (Acosta et al., 2004; Defrieri et al., 2005), so that the values of 15.5 for vermicompost and 17.0 for compost that were obtained in this study indicate that maturity of the products was reached by week 25 of decomposition.

The $\mathrm{N}-\mathrm{NO}_{3}$ content of the studied mixtures showed the effect of the composting system/time interaction $(\mathrm{P} \leq$ 0.0005). At the end of the experimental period, $\mathrm{N}-\mathrm{NO}_{3}$ concentrations, expressed in $\mathrm{mg} \mathrm{kg}^{-1}$, of $345 \pm 29$ for the product of vermicompost and $347 \pm 29$ for that of compost were observed, without this difference being significant $(\mathrm{P} \leq 0.9729) . \mathrm{N}-\mathrm{NO}_{3}$ concentrations in the substrates of the vermicompost and compost were very close to those found by Hao et al. (2004) in compost from cow manure and sawdust, reporting a concentration of $330 \mathrm{mg} \mathrm{kg}^{-1}$ on day 99 (Table 1).

$\mathrm{P}$ concentration presented an effect of the composting system/time interaction $(P \leq 0.044)$. Toward the end of the experimental period, a $\mathrm{P}$ concentration of 0.014 $\pm 0.0009 \%$ was observed for the final product of vermicompost and $0.016 \pm 0.0009 \%$ for compost, without this difference being significant $(\mathrm{P} \leq 0.2774)$. The $\mathrm{P}$ content of the final product of the vermicompost was lower than what was found by other authors. Castillo et al. (2002) reported P concentrations higher than $0.028 \%$ in vermicompost prepared with cow manure and kitchen waste, and mentioned that this high content is due to the fact that worms ingest large quantities of $\mathrm{P}$ with organic matter, which is digested by the intestine and accentuated by significant microbial activity, thus resulting in a high $\mathrm{P}$ content in what is excreted. However, the results of this work do not demonstrate that vermicomposting promotes an increase in $\mathrm{P}$ concentration (Table 1).

$\mathrm{K}$ content presented an effect of the composting system/time interaction $(\mathrm{P} \leq 0.0011)$. The final product of vermicompost presented a $\mathrm{K}$ concentration of $0.22 \pm$ 0.06 , and $0.55 \pm 0.06 \%$ for compost, with a significant difference of $\mathrm{P} \leq 0.0003$. The $\mathrm{K}$ content found in the final products of vermicomposting and composting in this study coincided with those reported by other authors (Castillo et al., 2002) for vermicompost based on cow manure. The $\mathrm{Ca}$ of the studied mixtures presented an effect of the composting system/time interaction $(\mathrm{P} \leq$ 0.0243). Toward the end of the experimental period, $\mathrm{Ca}$ content was observed with a mean of $0.63 \pm 0.08 \%$ for the final product of vermicompost and $0.60 \pm 0.08 \%$ for compost, without this difference being significant $(\mathrm{P} \leq$ 0.8275).

The $\mathrm{Mg}$ concentration showed an effect of the composting system/time interaction $(\mathrm{P} \leq 0.0407)$. The final product of vermicomposting obtained a mean of $\mathrm{Mg}$ content of $0.21 \pm 0.03 \%$, and $0.27 \pm 0.03 \%$ for compost, without these differences being significant $(\mathrm{P} \leq 0.0594)$. Fricke and Vogtmann (1993) reported an average $\mathrm{Mg}$ content in compost of $0.8 \%$, over dry weight, while values of $0.8 \%$ and $1.0-2.5 \%$ have been reported for vermiposting (Ducasal, 2002).

$\mathrm{Na}$ presented an effect of the composting system/ time interaction $(\mathrm{P} \leq 0.0001)$. At the end of the experimental period a concentration of $0.08 \pm 0.007 \%$ was observed for the final product of vermicompost and de $0.14 \pm 0.007 \%$ for that of compost, with a significant difference $(\mathrm{P} \leq 0.0001)$ of $0.058 \pm 0.01$ units. Both cases presented lower concentrations than those reported for compost and vermicompost by some authors (Ducasal, 2002), a condition that can be considered desirable given that $\mathrm{Na}$ is reported as a cation that can increase the salinity of the soil and can affect the growth and development of plants sensitive to this element (Castellanos et al., 2000).

There was no effect of the composting system/time interaction $(\mathrm{P} \leq 0.6244)$, nor of the composting system factor $(\mathrm{P} \leq 0.1627)$ on the variable of $\mathrm{Fe}$, which presented means of $733 \pm 29 \mathrm{mg} \mathrm{kg}^{-1}$ in vermicompost and $673 \pm$ $29 \mathrm{mg} \mathrm{kg}^{-1}$ in compost (Table1). However, the time factor had a quadratic effect $(\mathrm{P} \leq 0.0001)$ on the variable Fe. The factor composting system had a significant effect $(\mathrm{P}$ $<0.0001)$ on $\mathrm{Zn}$ concentration, presenting means of $68 \pm$ $1.76 \mathrm{mg} \mathrm{kg}^{-1}$ in the vermicomposting system and de $53 \pm$ $1.76 \mathrm{mg} \mathrm{kg}^{-1}$ in the composting system, with a difference 
of $14.45 \pm 2.48$ units. The factor time had a cubic effect $(\mathrm{P} \leq 0.0516)$ on the variable $\mathrm{Zn}$. Fricke and Vogtmann (1993) reported a maximum $\mathrm{Zn}$ content in compost of 230 $\mathrm{mg} \mathrm{kg}^{-1}$, to avoid problems of toxicity by this heavy metal (Table 1).

There was no effect of the composting system/time interaction $(\mathrm{P} \leq 0.2988)$ nor the composting system on the variable of $\mathrm{Mn}(\mathrm{P} \leq 0.5700)$, which presented means of $114 \pm 5.6 \mathrm{mg} \mathrm{kg}^{-1}$ for vermicompost and 109 $\pm 5.6 \mathrm{mg} \mathrm{kg}^{-1}$ for compost, with a difference of $4.57 \pm$ 8 units. Nevertheless, the time factor had a linear effect $(\mathrm{P} \leq 0.0026)$ on the variable $\mathrm{Mn}$. There was no effect of the composting system/time interaction $(\mathrm{P} \leq 0.3499)$ on the $\mathrm{Cu}$ variable, nor of the composting system $(\mathrm{P} \leq$ 0.1043 ) which presented means of $14 \pm 0.66 \mathrm{mg} \mathrm{kg}^{-1}$ for vermicompost and $12 \pm 0.66 \mathrm{mg} \mathrm{kg}^{-1}$ for compost, with a difference of $1.58 \pm 0.98$ units. However, the time factor had a quadratic effect $(\mathrm{P} \leq 0.0465)$ on the $\mathrm{Cu}$ variable (Table 1).

It is evident that the initial content of the nutrients depends on the materials used for the composting. For example, $\mathrm{P}$ is not lost because of volatilization or lixiviation, because of which its relative concentration should increase during the process. In this experiment, $\mathrm{P}$ concentration increased relatively, in both systems beginning in week 10 , which could be the result of the decreased quantity of dry matter while the net quantity of this element should remain the same as the initial quantity.

The $\mathrm{Ca}, \mathrm{K}$ and $\mathrm{Na}$ ions were concentrated due to the reduction of organic matter in the compost, while their concentration decreased in the vermicompost. Because there is no information about the nutritional requirements of the worm, it is difficult to assume that this decrease is due to feeding by the worms. Rather, it could be attributable to washing of these soluble salts with irrigation water, which could have caused a slight drainage through the substrate owing to the high moisture requirements of vermicomposting. On the other hand, the initial concentration of the micronutrient is highly variable, depending on the material used. Given that mineralization leads to a reduction in the organic matter content, the micronutrient content of the compost should generally increase during the process. In general, this behavior was observed for the four evaluated micronutrients with both decomposition processes beginning at week 10 , which clearly coincides with the decrease in carbonated components in the system.

\section{Phytotoxicity analysis}

Many substances found in immature composting products can reduce the germination rate of seeds depending on their concentration in the substrate used. This effect can be directly related to the decrease in the concentration of organic acids in the material. Because the information form this test can indicate the maturity of the compost, the phytotoxicity study was conducted in two parts during weeks 21 and 25. It also included the original mixture and a concentrated solution of $\mathrm{Zn}$ as a positive control of inhibition. Figure 2 shows the germination index calculated for the different organic residuals used in the study, considering that for the control this index is $100 \%$.

The germination indices in the vermicompost and compost from 25 wk were significantly higher $(\mathrm{P} \leq 0.0059)$, with means of $134 \pm 3.08 \%$ and $121 \pm 3.08 \%$ respectively. In accordance with these results, the vermicompost product from $25 \mathrm{wk}$ provides a more adequate mean for the germination of lettuce seeds; indicating a decrease in the unfavorable effects on the seeds by the action of certain phytotoxic substances. There were no significant differences $(\mathrm{P} \leq 0.5936)$ in the compost between weeks 21 and 25 , which presented means of $111 \pm 3.08 \%$ and $121 \pm 3.08 \%$, respectively. Both decomposition processes notably increased this index, including exceeding $100 \%$, which indicates a clear stimulating effect of these organic fertilizers on germination.

Zucconi et al. (1981) identified as a phytotoxic effect those cases in which the germination index is lower $50 \%$, which was observed in the initial manure-sawdust mixture, with a mean of $42 \pm 3.08 \%$. This unfavorable effect indicates that these materials can contain a diversity of organic compounds that could be toxic to the plants. The percentage of germination for the initial mixture was less than $50 \%$, which could be related basically to its high salinity. These results should be taken into account by agricultural producers who incorporate these or other fresh livestock residues as soil improvers without prior treatment.

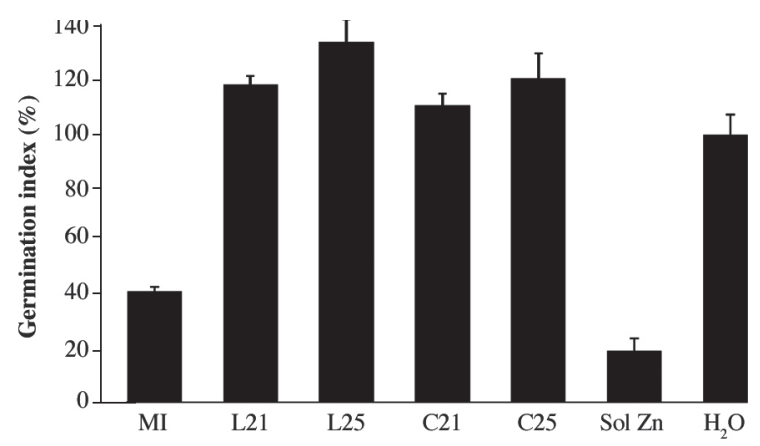

M-I = initial mixture, $\mathrm{L} 21=$ vermicompost at $21 \mathrm{wk}, \mathrm{L} 25=$ vermicompost at $25 \mathrm{wk}, \mathrm{C} 21=$ compost at $21 \mathrm{wk}, \mathrm{C} 25=$ compost at $25 \mathrm{wk}, \mathrm{Sol} \mathrm{Zn}=$ solution of $\mathrm{Zn}$.

Figure 2. Germination index of lettuce in vitro with extracts of vermicompost and compost at 21 and 25 wk of decomposition. 


\section{Storage process}

The most important factor that affects the successful use of compost in agricultural practices is the degree of maturity and stability. Maturity refers to the degree of decomposition of organic substances and stability is related to the levels of microbial activity of the biomass (Fuente et al., 2006).

The average values of the variables $\mathrm{pH}$, organic $\mathrm{C}$, total $\mathrm{N}, \mathrm{C} / \mathrm{N}$ ratio, $\mathrm{N}-\mathrm{NO}_{3}, \mathrm{P}, \mathrm{K}, \mathrm{Ca}, \mathrm{Mg}, \mathrm{Na}, \mathrm{Fe}, \mathrm{Zn}, \mathrm{Mn}$ and $\mathrm{Cu}$ in mature and stored vermicompost and compost are shown in Table 1. The storage period increased the $\mathrm{N}$ content of the recently prepared fertilizers. The literature recommends contents of this element higher than $2 \%$ so that the compost continues the processes of humufication and mineralization in the soil (Melgarejo et al., 1997; Ducasal, 2002), which is obtained in storage. Flavel and Murphy (2006) recommend a $\mathrm{C} / \mathrm{N}$ ratio lower than 12 as an indicator of the maturity of composting products, which was reached in this study during storage. This shows that the storage period is effective for stabilizing the organic matter through the decrease in $\mathrm{C}$ concentration and the increase in $\mathrm{N}$, resulting in a reduction of the $\mathrm{C} / \mathrm{N}$ ratio of stored fertilizers. According to these results, the storage period can increase $\mathrm{N}-\mathrm{NO}_{3}$ content, which is important because both $\mathrm{N}-\mathrm{NO}_{3}$ and $\mathrm{N}-\mathrm{NH}_{4}$ are absorbed by plants and constitute important forms of applying $\mathrm{N}$ fertilizer to crops (Castellanos et al., 2000). Consequently, this increase can be considered positive. Nevertheless, $\mathrm{N}-\mathrm{NO}_{3}$ can represent contamination of water and soils given that it can be lost by lixiviation. Given this, some characteristics of the soil should be taken into consideration, such as texture, organic matter content and the infiltration velocity, when determining the length of the storage period.

$\mathrm{P}$ content decreased in both systems of composting during the storage period, which is contrary to what is expected given that $\mathrm{P}$ is not lost through volatilization or lixiviation. Nevertheless, for Hansen et al. (2001) the handling and storage of manure before its incorporation into the soil can affect the forms and concentration of $\mathrm{P}$ due to differences in microbial species, oxygen, $\mathrm{pH}$ and temperature. Given this, the reduction of $\mathrm{pH}$ during the storage of vermicompost and compost to levels of 6.0 and 7.42, respectively, can influence the reduction of P. As well, microbial activity can exhaust the organic components as a source of P. Because of this, this nutrient can provide useful information about the degree of stability of composting and vermicomposting products.

There was a significant increase in $\mathrm{K}$ in the vermicompost, which could be because $\mathrm{K}$ is essential for worm growth. Its absorption from the substrate promoted the expected increase by reducing dry matter from the substrate. However, the reduction of the nutrient that was observed in the compost was probably due to the lixiviation of this soluble salt from the medium.

The concentrations of $\mathrm{Ca}, \mathrm{Mg}$ and $\mathrm{Na}$ increased in both substrates after storage, which is expected given the decrease in dry matter. Despite the final increase in $\mathrm{Na}$, the vermicompost always presented the lower level, which can be of special interest in the selection of a soil improver because of the negative effects that heavy incorporations of this element can provoke in soils. Even though the storage process appears to notably increase Ca content in stored vermicomposts and composts, they do not reach the concentration recommended by Ducasal (2002), a minimum of $2 \%$ for vermicompost and $3.8 \%$ for composts.

As well, Fricke and Vogtmann (1993) recommended a maximum content of $230 \mathrm{mg} \mathrm{kg}^{-1}$ of $\mathrm{Zn}$, and $30-43$ $\mathrm{mg} \mathrm{kg}^{-1}$ of $\mathrm{Cu}$ over the dry weight in the compost to avoid problems of toxicity by these elements, which was achieved satisfactorily in both substrates. Only Fe concentration decreased sharply during storage, probably owing to the precipitation of this element, which is highly soluble in water. The storage process generally tends to increase the stability of composting and vermicomposting products in a similar manner, which allows for removing the worms from the material in decomposition once it has reached maturity and integrate them in the decomposition of new organic matter, given that the humification process does not occur in the worm digestive system of the worm.

\section{CONCLUSIONS}

Even though both treatments, compost and vermicompost, had the typical physical-chemical characteristics of a composted product, the maximum temperature in the reactors was $28.3{ }^{\circ} \mathrm{C}$, in effect, neither reactor reached thermophile temperatures common in this practice. Consequently, the substrates produced in this study should be considered as semi-composted. Another relevant observation was the absence of incremental effects in nutritional content commonly associated with vermicomposting, which supposes an advantage of using this product over that of traditional composting. However, a higher $\mathrm{pH}$ was found in the compost, with a value of 8.5 compared to a $\mathrm{pH}$ of 7.3 for the vermicomposting. This characteristic should be taken into consideration when the semi-composted product is applied to the soil as an improver.

With the environmental conditions under which the study was conducted, with an ambient temperature range of $1-40{ }^{\circ} \mathrm{C}$, the composting and vermicomposting products reached maturity at 25 wk of decomposition, which is relevant for their production in regions with this regimen of summer temperatures, as in northern Mexico. 


\section{ACKNOWLEDGEMENTS}

These experiments were carried out with funds from PIFI 2006-2007 (Integral Program of Institutional Strengthening) through support to the academic CA02 "Animal Feed Systems" and CA11 "Temperate Zone Fruits" of the Universidad Autónoma de Chihuahua. The authors are grateful to CONACYT (National Council for Science and Technology) for support to the post-graduate studies of Adriana Ofelia Hernández Ph.D.

\section{RESUMEN}

Efecto de la lombriz roja californiana (Eisenia foetida) en la dinámica de nutrientes de una mezcla de materiales semicompostados. Se evaluó la eficiencia de los procesos de compostaje con y sin la adición de lombriz roja californiana (Eisenia foetida) usando estiércol de vacas lecheras para la generación de abonos orgánicos. Como indicadores de madurez se evaluaron varios parámetros fisicoquímicos tales como temperatura, $\mathrm{pH}$, relación $\mathrm{C} / \mathrm{N}$, fitotoxicidad y macro y micronutrientes durante 25 y 54 semanas (productos maduros y almacenados, respectivamente). En el análisis estadístico se usó un modelo lineal con cuatro repeticiones que incluyó como efectos fijos los sistemas de compostaje y el tiempo. Se realizó análisis de varianza y comparación de medias mediante contrastes ortogonales. A las 25 semanas ambos sistemas redujeron la relación $\mathrm{C} / \mathrm{N}$ a valores de 15,5 en vermicompost y de 17,1 en semi-compost, además se incrementó el contenido de $\mathrm{N}$-total, $\mathrm{N}-\mathrm{NO}_{3}, \mathrm{Ca}$ y de algunos micronutrimentos. La concentración de $\mathrm{K}$, y Na fueron más altos en compost que en vermicompost. La media de $\mathrm{pH}$ presentó diferencia para los sistemas de descomposición. El índice de germinación usando semillas de lechuga (Lactuca sativa L.) var. Grandes Lagos in vitro de los productos de descomposición se incrementó en la semana 25 indicando el grado de madurez alcanzado. El efecto del almacenamiento permitió alcanzar una mayor estabilidad de los productos al reducir la relación $\mathrm{C} / \mathrm{N}$ a 8,13 para vermicompost y de 7,05 para compost, así como un incremento en el contenido de $\mathrm{N}$ disponible en forma de $\mathrm{N}^{-\mathrm{NO}_{3}}$ en el caso del compost y en el contenido de $\mathrm{Ca}$, $\mathrm{Mg}, \mathrm{Na}, \mathrm{Zn}, \mathrm{Mn}$ y $\mathrm{Cu}$ en ambos sistemas.

Palabras clave: abono, orgánico, maduración, estabilidad.

\section{LITERATURE CITED}

APHA. 1992. Standard methods for the examination of water and wastewater. $18^{\text {th }}$ ed. American Public Health Association (APHA), Washington D.C., USA.
ASTM. 2000. Standard test methods for moisture, ash and organic matter of peat and other organic soils. Method D 2974-00. American Society for Testing and Materials (ASTM), West Conshohocken, Pennsylvania, USA.

Acosta, Y., J. Paolini, y E. Benítez. 2004. Índice de humificación y prueba de fitotoxicidad en residuos orgánicos de uso agrícola potencial. Revista de la Facultad de Agronomía de Caracas 21:1-6.

Castellanos, J.Z., J.X. Uvalle-Bueno, y A. AguilarSantelises. 2000. Manual de interpretación de análisis de suelos y aguas. Plantas Y ECP. $2^{\mathrm{a}}$ ed. INIFAP- Gto. Chapingo-Estado de México. p. N 1-6. Colección Instituto de Capacitación para la Productividad Agrícola INCAPA, Celaya, Guanajuato, México.

Castillo, A.E., S.H. Quarín, y M.C. Iglesias. 2002. Caracterización química y física de composta de lombrices elaborados a partir de residuos orgánicos puros y combinados. Agricultura Técnica (Chile) 60:74-79.

Celis, J., M. Sandoval., E. Zagal, and M. Briones. 2006. Effect of sewage sludge and salmon wastes applied to a Patagonian soil on lettuce (Lactuca sativa L.) germination. Revista de la Ciencia del Suelo y Nutrición Vegetal 6:13-25.

Defrieri, R.L., M.P. Jiménez, D. Effron, y M. Palma. 2005. Utilización de parámetros químicos y microbiológicos como criterios de madurez durante el proceso de composteo. Agriscientia 22:25-31.

Ducasal, R.R. 2002. Biofertilizantes. Ganadería Integral Vizur. p. 1. Fundación Produce Sinaloa A.C., Culiacán, Sinaloa, México.

Ferrera, C.D., y A. Alarcón. 2001. La agricultura del suelo en la agricultura sostenible. Ciencia Ergo Sum 8:175183.

Flavel, T.C., and D.V. Murphy. 2006. Carbon and nitrogen mineralization rates after application of organic amendments to soil. Journal of Environmental Quality 35:183-196.

Fricke, K., and H. Vogtmann. 1993. Quality of source separated compost. BioCycle 34:64.

Fuente, B., N. Bolan, R. Naidu, and M. Mora. 2006. Phosphorus in organic waste-soil systems. Revista de la Ciencia del Suelo y Nutrición Vegetal 6:64-83.

Hansen, B., H.F. Alrøe, and E.S. Kristensen. 2001. Approaches to assess the environmental impact of organic farming with particular regard to Denmark. Agriculture Ecosystems \& Environment 83:11-26.

Hao, X., C. Chang, and F.J. Larney. 2004. Carbon and nitrogen balances and greenhouse gas emission during cattle feedlot manure composting. Journal of Environmental Quality 33:37-44. 
Jurado, J. 2004. Encuestas aplicadas a productores y procesadoras locales 2004. p. 23-26. Fundación Produce Chihuahua, Chihuahua, México.

Kowalchuk, G., Z. Naoumenko, P. Derikx, A. Felske, J. Stephen, and I. Arkhipchenko. 1999. Molecular analysis of ammonia-oxidizing bacteria of the $\beta$ subdivision of the class Proteobacteria in compost and composted materials. Applied and Environmental Microbiology 65:396-403.

Madrid, C., y Y. Castellanos. 2001. Efecto de activadores sobre la calidad de composts elaborados con cachaza y bagazo de caña de azúcar. Venesuelos $6(1$ y 2):22-28.

Melgarejo, M.R., M.I. Ballesteros, y M. Bendeck. 1997. Evaluación de algunos parámetros fisicoquímicos y nutricionales en humus de lombriz y derivados de composta. Revista Colombiana de Química 26:2.

Mondini, C., M.T. Dell Abate, L. Leita, and A. Enedetti. 2003. An integrated chemical, thermal and microbiological approach to compost stability evaluation. Journal of Environmental Quality 32:2379-2386.

Nogales, R., C. Cifuentes, and E. Benitez. 2005. Vermicomposting of winery wastes: A laboratory study. Journal of Environmental Science and Health Part B-Pesticides Food Contaminants and Agricultural Wastes 34:659-573.
NRAES. 1999. Field guide to on-farm composting. p. 2728, 32. Nature Resource, Agriculture and Engineering Service (NRAES), Cooperative Extension, Ithaca, New York, USA.

Richard, T. 1995. Moisture and carbon/nitrogen ratio calculation. Cornell Waste Management Institute, Department of Agricultural and Biological Engineering, Ithaca, New York, USA.

Santamaría-Romero, S., C.R. Ferrera, S.J. Almaraz, S.A. Galvis, y B.I. Barois. 2001. Dinámica y relaciones de microorganismos, C-orgánico y N-total durante el composteo y vermicomposteo. Agrociencia 35:377384.

SAS Institute. 2001. User's guide. Statistics version 8.2. SAS Institute, Cary, North Carolina, USA.

Soto, G., y C. Muñoz. 2002. Consideraciones teóricas y prácticas sobre el compost, y su empleo en la agricultura. Manejo Integrado de Plagas y Agroecología (Costa Rica) 65:123-125.

Zucconi, F., A. Peram, M. Forte, and M. De Bertolidi. 1981. Evaluating toxicity of immature compost. Biocycle 22:54-56. 